\title{
Tools to improve palliative care: e-prescription and Patient's Internet Account - legal status analysis
}

\begin{abstract}
The implementation of new technology is a response to the challenges of the current health system, such as ageing population and rising treatment costs. Focusing on improving the quality of the services provided and increasing access to treatment guarantees a feeling of safety in the therapeutic process. Amendments introduced to the law and implementing the idea of digitisation of the health care system may turn out to be significantly beneficial for both the medical personnel and the relatives taking care of the patients. New solutions can be applied by Home Hospices, whose functioning is a significant challenge for organizational and financial reasons.

The aim of this paper was to analyse current legal regulations governing electronic prescribing. In addition, the impact of e-prescription and related eHealth elements on the availability and quality of palliative care services was assessed. Modern information and communications technology can solve many problems related to access, quality and cost-effectiveness of medical services, in particular those concerning palliative care. E-prescription is a tool that can significantly improve patient care through simplified prescribing rules. New rules for issuing and confirming orders for medical devices also make it much easier for carers.

Palliat Med Pract 2020; 14, 2: 101-107

Key words: electronic prescribing, eHealth, telemedicine, palliative medicine, healthcare delivery, pharmacy law
\end{abstract}

\section{Abbreviations}

ICT system - information and communications technology P1 Platform - Electronic Platform for Collection, Analysis and Sharing of Digital Resources on Medical Events

MIS - Medical Information System

PIA - Patient's Internet Account

CHCIS - Centre for Health Care Information Systems NFZ - National Health Fund (Polish: Narodowy Fundusz Zdrowia)

PHC - Primary Health Care

RMA - Registry of Medical Assistants

ZUS - Social Insurance Institution (Polish: Zakład Ubezpieczeń Społecznych)

\section{Introduction}

In 2019, there was a breakthrough in the process of computerisation of health care system - within a few months e-prescription, e-sick-note and electronic order for medical devices were implemented in Poland, as well as access to the Patient's Internet Account (PIA) was popularised. All the actions are consequences of strategy of information society development in Poland, adopted in 2018 [1]. Digitisation of health care is a solution that increases the quality of medical services provided and enables faster and more accurate therapeutic decision-making. The implementation of new technology is a response to the challenges of current health system, such as ageing

\footnotetext{
Address for correspondence:

Natalia Susłowska

Department of Medical and Pharmaceutical Law, Medical University of Gdańsk

e-mail: nataliasuslowska@gmail.com
}

Palliative Medicine in Practice 2020; 14, 2, 101-107

Copyright (C) Via Medica, ISSN 2545-0425

DOI: 10.5603/PMPI.2020.0010 
population and rising treatment costs. Focusing on improving the quality of the services provided and increasing access to treatment guarantees a feeling of safety in the therapeutic process [2].

Research on the availability of palliative care has shown that there is still a lack of units of this type in some Polish districts. In Poland, among the available forms of palliative care, home hospice is most frequently used. Regulation of the President of the National Health Fund [3] (Polish: NFZ) defines the minimum personnel requirements to be met by a facility providing home palliative care: one doctor provides care up to 30 patients. In accordance with the terms of the agreement concluded with NFZ, a doctor must have (at least commenced) a specialisation in palliative medicine or a completed course related to this field. The basic requirement for providing home palliative care is 24-hour availability [4]. The requirements imposed on Home Hospices make the functioning of such an institution challenging for organisational and financial reasons.

Amendments to the law implementing the idea of digitisation of health care system can be significantly beneficial for medical personnel and carers. Current legal regulations enable patient care without direct contact. The provision of health services at a distance is based on Article $3 \mathrm{sec} .1$ of the Act of 15 April 2001 on therapeutic activities, which indicates that therapeutic activities may be carried out using ICT systems [5]. In addition, Article $2 \mathrm{sec}$. 4 of the Act of 5 December 1996 on the professions of doctor and dentist states the services that a doctor may provide through communications systems: health status examination, diagnosis and prevention of diseases. In addition, treatment and rehabilitation as well as provision of advice can take place without personal contact with the patient. The doctor is also authorised to issue medical certificates and medical opinions in absentia. It is worth noting that the latest provisions of the Act allow a prescription to be issued to continue the treatment of a patient without prior examination if it is justified by the patient's health condition reflected in the medical records. The same rules apply to orders for medical devices (Article $42 \mathrm{sec}$. 2 of the Act on Professions of Doctor and Dentist). Provisions introduced on 16 March 2020 complemented the Regulation on guaranteed services within palliative and hospice care with provisions that legalize and allow the provision of medical advice and home visits in terms of Home Hospice using ICT systems. The use of new communications systems is conditional on ensuring that such a procedure does not threaten to impair the patient's health[6]. The current e-prescription and electronic order for medical devices make it much easier to treat patients, including those receiving palliative care. The aim of this paper was to analyse current legal regulations governing electronic prescribing. In addition, the impact of e-prescription and related eHealth elements on the availability to palliative care services as well as their quality was assessed.

\section{E-prescription and e-order for medical devices}

On 1 March 2018 the provisions of the Act on the amendment of certain acts in connection with the implementation of e-prescription [7]. Among 8 amended legal acts were i.a. Act of 5 December 1996 on the professions of doctor and dentist [8], the Act of 6 September 2001 on Pharmaceutical Law [9], as well as the Act of 12 May 2011 on coverage of drugs, foodstuffs for particular nutritional uses and medical devices [10]. Article 95b of the Act on Pharmaceutical Law states electronic prescribing as a preferential way of issuing prescriptions. A paper prescription may be issued in certain cases:

- Lack of access to the ICT system enabling the management of e-prescriptions

- Necessity to prescribe a medication for a person with an unspecified identity

- Temporary practice of the medical profession on the territory of the Republic of Poland

- Recommending medicines in the target import procedure.

When prescribing the medicine pro auctore as well as pro familiae one can use a paper version of the prescription. It should be noted that since August 2019, the list of persons to whom an entitled person can recommend the medicine has been extended. Currently, in addition to relatives of straight line and spouses, this group also includes relatives of lateral line to the degree of relatedness among siblings' children, as well as persons sharing a relationship with the prescriber. Pursuant to Article $56 \mathrm{sec}$. 2 od the Act of 28 April 2011 on the health care information system, paper prescriptions that did not meet the abovementioned conditions could be issued until 7 January 2020. In order to start electronic prescribing, medical institutions were obliged to connect to the Electronic Platform for Collection, Analysis and Sharing of Digital Resources on Medical Events (P1 platform) by 31 December 2019. Pharmaceutical law specifies in detail the data that must be included in the prescription in order for it to be dispensed (Table 1). The scope of this information is similar for paper and electronic prescriptions, irrespective of the level of coverage for the products prescribed.

The prescriber is obliged to indicate the date of prescription issuance; in the case of a prescription with a delayed date of dispensing they are obliged 
Table 1. List of obligatory data on a prescription issued in electronic form - legal status as of 6 February 2020

\begin{tabular}{|c|c|}
\hline Patient's details & $\begin{array}{l}\text { Full name } \\
\text { Address (place name, street, house number, postcode, premises number, if any) } \\
\text { PESEL[Personal Identification Number] or passport series and number in case of fore- } \\
\text { igners } \\
\text { Patient's date of birth, if it cannot be determined from other data on the prescription } \\
\text { Patient's code for additional entitlements, if applicable }\end{array}$ \\
\hline $\begin{array}{l}\text { Details on the institution } \\
\text { where prescription has } \\
\text { been issued }\end{array}$ & $\begin{array}{l}\text { Name of the place where health services are provided } \\
\text { Address (place name, postcode, street, house number, premises number, if any) and - } \\
\text { in the case of persons carrying out medical activity only at the place of a sick call - the } \\
\text { address of the place for receiving calls and the place where medical records are kept } \\
\text { Identifier of the place of providing services (code made up of the part of the code from } \\
\text { the identification code system of the health care institution) } \\
\text { Telephone number available at the place of providing services }\end{array}$ \\
\hline Prescriber's details & $\begin{array}{l}\text { Full name of the prescriber } \\
\text { Professional qualifications, including a professional title, } \\
\text { Number of the right to practise medicine } \\
\text { Telephone number for direct contact with the prescriber } \\
\text { Qualified electronic signature, trusted signature or personal signature, or using the } \\
\text { method of confirming the origin and integrity of data available in the ZUS (Social } \\
\text { Insurance Institution) system }\end{array}$ \\
\hline $\begin{array}{l}\text { Data on the medicinal } \\
\text { product, foodstuff for par- } \\
\text { ticular nutritional uses or } \\
\text { medical device prescribed }\end{array}$ & $\begin{array}{l}\text { Common name (international or commercial) } \\
\text { Form (if the product prescribed is in more than one form) } \\
\text { Dose (if the product prescribed is in more than one dose) } \\
\text { Amount of the product prescribed } \\
\text { Dosing method }\end{array}$ \\
\hline
\end{tabular}

to specify the dispensing date from a date. During a single visit, the doctor may prescribe their patient the amount of drug necessary for 360 days of treatment, calculated on the basis of the dosing method specified in the prescription. In addition, on the basis of their current medical knowledge, the prescriber may determine the date of e-prescription dispensing up to 365 days. In the absence of an extended validity of prescription, the patient should purchase the medicinal products prescribed within 30 days [11]. The extended validity of prescription does not apply to medicinal products for which separate provisions precisely define the prescription dispensing date, i.e. antibiotics for internal and parenteral use, immunological products produced individually for the patient and medicines containing psychotropic and psychoactive substances. If filling the prescription is urgently required, it should be labelled with the term "cito".

It is essential that after 30 days from the date of e-prescription issuance (or the date of e-prescription dispensing from a date), the e-prescription is dispensed with the exception of days that have already passed. This means that despite specified validity date of the prescription, i.e. 365 days, a patient must start dispensing the prescription within first 30 days of the prescription issuance if they want to receive the whole prescribed amount of medicine. According to the Announcement of the Ministry of Health of 28 November 2019, the reduction of the amount of medicinal product subject to medical prescription is made only during the first partial dispensing of the prescription [12]. It should be noted that the maximum amount of the product the patient may receive from a pharmacy at once is necessary for 180 days of application, calculated on the basis of the dosing method specified in the prescription. As a result, a patient who has been prescribed 360 days of drug treatment must visit the pharmacy at least twice in order to purchase the whole drug treatment prescribed. Regulations do not specify the minimum time that must elapse between successive dispensing of prescription, which means that it is permissible to purchase the whole 360-day drug treatment in two days, provided that two separate fiscal transactions are made.

Unlike paper prescriptions, maximum one medicinal product may be prescribed on a single document. If more than one e-prescription is issued, the prescriber may, in order to facilitate their filling, combine these prescriptions into a package. One package may contain up to five e-prescriptions. A prescription issued in electronic form is stored in MIS, which is ICT system for processing data on the health services provided and planned, which are made available by service providers [13]. The content of e-prescription that has been saved in MIS cannot be modified. If the prescription has to be modified, it should be annulled and new prescription should be issued. Only the prescriber can annul it. E-prescriptions are stored in MIS for at least 5 years, from the end of the calendar year in which they were dispensed. In the case of prescriptions for reimbursed 
medicines, this time is counted from the end of the calendar year in which the drug coverage occurred.

Pursuant to Article 96b of the Act on Pharmaceutical Law, it is obligatory that the patient to whom a prescription has been issued in electronic form receives the following information:

- Access key for e-prescription or package of e-prescriptions (40 digits)

- Access code for dispensing a prescription in a pharmacy in combination with PESEL[Personal Identification Number] (4 digits)

- E-prescription identifier which was given by the P1 system during registration to the Registry of Institutions Responsible for Therapeutic Activities [Polish: Rejestr Placówek Wykonujących Działalność Leczniczą]

- Date of prescription issuance, the prescription dispensing date from a date

- Patient's full name

- The prescriber's details, including the number of the right to practise medicine and the telephone number for direct contact

- Details of the medicinal product prescribed, including its name, form, dose, amount and dosing method. This information is also included in PIA. The prescriber should make sure that the patient has access to PIA, otherwise the above-mentioned details must be provided during the visit.

The Act specifies precisely three ways of giving the patient access to e-prescription and to the above-mentioned information. According to Article $96 \mathrm{~b} \mathrm{sec} .2$ of the Act on Pharmaceutical Law, e-prescription can be sent electronically to the e-mail address indicated or via text message to a telephone number. It should be noted that the text message sent must contain at least four-digit access code together with the information on the necessity of giving PESEL[Personal Identification Number] during dispensing the prescription in a pharmacy. Receiving e-prescription in this way is only possible if the patient makes available their e-mail address and telephone number in the health care information system. If the patient does not share these contact details with the system, the prescriber is obliged to give access to e-prescription and necessary data by means of an information printout which should also be issued to the patient whenever they request it.

It is important to note that Article 96b sec. 3 of the Act on Pharmaceutical Law lays down that an informational printout may only be issued by the prescriber. This follows from the wording that no third party (e.g. registrar or nurse) may participate in the process of submission of the printout. The solution to this limitation was introduced by the Act of 19 July
2019 on the amendment of certain acts in connection with the implementation of solutions in the area of eHealth[14]. The above-mentioned regulations made it possible to grant the authorisation to issue electronic prescriptions on behalf of a doctor by persons performing medical professions and performing auxiliary activities when providing health services. This group also includes the staff dealing with the maintenance of the ICT system supporting e-prescriptions. These above-mentioned persons may be present at the provision of health services and are also authorised by the health care institution to process patients' personal data. The authorisation to issue a prescription may be granted for a maximum period of 12 months. A consequence of this authorisation is the obligation to maintain confidentiality of any information obtained in connection with the issue of a prescription, even after the patient's death. The authorisation may be granted via RMA, which is administered by the Ministry of Health [8]. It should be noted that the assistance of a medical assistant can only be used for electronic prescriptions, and the law does not provide for such assistance for issuing paper prescriptions.

Unlike paper prescriptions, the law does not specify the format of the e-prescription's information printout. This document may take a format of existing prescriptions or any other format, depending solely on the settings of a printer in the doctor's surgery. If health care services are provided at the place of a sick call, it is permissible to submit the e-prescription in another form, agreed with the patient, containing at least an access key or an access code to prescription, as well as the name of the prescribed medicinal product. In accordance with the applicable provisions, it is incorrect to provide the patient only with a handwritten access code to the e-prescription without providing the remaining mandatory data.

According to the Act of 5 December 1996 on Professions of Doctor and Dentist, the person entitled to issue a prescription is obliged to specify the level of payment for a medicinal product concerned if there are two or more payments in the list of reimbursed medicines [8]. This obligation meets with dissatisfaction and protests of the medical community. Cases have been reported where a doctor, due to neither limited time nor unavailability of an accessible source of knowledge regarding reimbursement levels (nor for fear of a penalty), prescribed the medicine in full payment, despite the patient's right to drug coverage. In addition, studies conducted in 2013 have shown that this obligation almost doubles the time spent on issuing a paper prescription [15].

The computerisation of the health care system is aimed at improving and facilitating the provision of 
health services. Therefore, in accordance with the Act of 28 April 2011 on the health care information system, CHCIS is obliged to make available a free of charge IT tool for determining the level of payment for particular medicinal products listed on the e-prescription. The Minister of Health should include in the Public Information Bulletin the data enabling the installation of this tool in the cabinet programme, as well as its updating [13]. It is essential that neither the doctor nor the health care institution will be responsible for possible consequences of the tool's malfunctioning in terms of inadequate determination of the level of payment [8].

Another facilitation for chronically ill patients are new rules for confirming orders for medical devices. Many patients receiving palliative care use such medical devices as adult diapers, urinary catheters, pillows and anti-bedsore mattresses every day. From 1 January 2020 it is possible to electronically confirm the order for the supply of the above-mentioned products; from 1 April 2020 this form of verification will be standard. Until now, patients (or their carers) were forced to visit the NFZ Branch on a monthly basis in order to obtain a stamp confirming their entitlement to purchase reimbursed medical devices. When using new order templates, the patient will be able to go to the pharmacy immediately after receiving the order. The new rules allow issuing and confirming orders regardless of the patient's place of residence [16]. It worth noting that the order may be issued after a prior examination of the patient, which may be carried out in person or via remote communications systems. When prescribing medical devices that are available to the patient on a monthly basis, the order may be issued only on the basis of medical records [10].

\section{Patient"s Internet Account}

PIA is a module of P1 platform, which allows access to patient data stored in MIS and in the Medical Services Registry System of the National Health Fund [13]. PIA enables the patient, or their statutory representative, to have access to information on the health services provided and planned, as well as the amount of public funds spent on their financing. In the section concerning issued and dispensed e-prescriptions, one can have a close look at the amount of financial coverage for particular medicinal products applied by the patient. By means of PIA the patient may authorise selected persons to the access to medical records, as well as make available personal or individual medical data of the provider within a scope in terms of time and subject matter specified by the patient. In PIA the beneficiary may indicate a person authorised to obtain all information about their health.
Another function of PIA, crucial for patient's security, is their access to information on medicinal products that have been withdrawn from the market, if such products were purchased by them on the basis of prescription. Owing to the obligation to generate an electronic document on prescription dispensing, the recipient of services has permanent access to data concerning the medicinal product dispensed, including its expiry date and batch number. It also records information concerning the pharmacy from which the medicine was dispensed as well as details of a worker dispensing the prescription. It should be noted that the above-mentioned capabilities of PIA are only a few examples that are crucial from the point of view of the functionality of electronic prescription.

PIA completely eliminates the anonymity of health care system employees and the data concerning the treatment process are transparent. It is worth noting that PIA simplifies submitting applications and complaints to the Patient Ombudsman, Minister of Health and National Health Fund. Such solution is expected to improve the quality of medical and pharmaceutical services provided.

Access to PIA is possible after authentication of the recipient of services, their statutory representative or a person authorised by him by means of electronic identification [17]. The primary means of electronic identification, which a patient can use to access PIA, is a trusted profile that any citizen with PESEL number can have. In order to start using the trusted profile, one has to submit an electronic application that must then be confirmed in one of three ways. The first method requires a visit to the confirmation point where an authorised person establishes the applicant's identity on the basis of documents presented. In addition, the applicant confirms their wish to have a trusted profile by signing the application form on paper. The applicant may also confirm the trusted profile alone if they have a qualified electronic signature or with the use of an electronic bank account. A confirmed and active trusted profile allows an electronic signature [18].

The function of the confirmation point may be performed by Consul, Head of Tax Office, Voivode, ZUS or NFZ - they may give powers to confirm the trusted profile on their behalf to persons employed in entities carrying out tasks related to PHC. These powers may be obtained by PHC doctor, nurse or midwife, as well as another person employed in such an entity, provided that the personal data (first name, surname, PESEL) are reported to NFZ [17]. The staff of PHC clinics can therefore help patients to activate access to PIA for remuneration. There are provisions in the law stipulating that in the years 2020-2022 the Minister of Health may provide NFZ with funding in 
the amount of PLN 150,000 for performing a function of confirmation points confirming the trusted profile by PHC providers and for the campaign promoting the PIA activation. The amount of the subsidy depends on the number of activated PIAs by the staff of PHC clinics [19]. According to the Regulation of the President of the National Health Fund (NFZ), the remuneration for activating single PIA by confirming the trusted patient profile is PLN 36.90 gross for the first 150 activated PIAs [20]. Recently, the public mobile application "mObywatel" [English: mCitizen] has also given the opportunity to access to non-dispensed electronic prescriptions.

\section{Summary}

The purpose of palliative care is to provide the most effective treatment of symptoms, alleviating suffering, providing psychosocial and spiritual support to patients and carers and improving the patients' quality of life [21]. One of key elements of care is securing patients with necessary medicines (especially painkillers), specialist dressings and medical devices to ensure comfort and hygiene of patients. E-prescription is a tool that can significantly improve patient care through simplified prescribing rules and continuation of the treatment. The new rules of issuing and confirming orders for medical devices are also very beneficial for the carers of seriously ill patients who have been exempted from the obligatory monthly visits to NFZ Branches. PIA provides easy access to medical data for both doctors and carers, which facilitates monitoring and management in palliative care.

The potential of many mobile applications and new information technologies in health care is promising. Modern technological solutions allow increased involvement of the patient in the treatment process and constant monitoring of disease symptoms. The use of these tools can therefore prevent unnecessary hospitalisations and sudden medical interventions [22]. Modern information and communications technology can solve many problems related to access, quality and cost-effectiveness of medical services [21]. In accordance with Article 11 of the Act of 28 April 2011 on the health care information system, palliative care units (including Home Hospices) are obliged to keep medical records in electronic form [13]. Doctors providing home care services should keep medical records in accordance with the rules on medical records for home visits. In addition, every visit by the Home Hospice staff involves completing a medical record at the patient's home [23]. However, the diversity of services provided in Home Hospices by medical staff of different professions makes the development of an electronic documentation system tailored to the needs of palliative care a major challenge. Commercial service providers providing software for keeping medical records in palliative care units are entering the market. The applications offered allow to prepare prescriptions at the patient's home and entries made are visible to other medical staff taking care of the patient [24].

The introduction of telemedicine into palliative care results in reduced expenditure on consultations and shortened time spent by doctors during transport as well as increased satisfaction of patients and families [25]. Telemedicine is currently used in approx. 8\% of medical institutions in Poland [26]. Computerisation of health care system is a key factor determining the development of this area, while e-prescription, e-referrals, e-sick notes and e-orders for medical devices provide an opportunity to increase the efficiency of such services. The presented in this article benefits of modern technology applied in palliative care argue for the need to disseminate and allocate more financial resources to their development.

\section{Conflict of interests}

Authors declare no conflict of interest.

\section{Funding}

This study has no funding.

\section{References}

1. Ministerstwo Spraw Wewnętrznych i Administracji, Strategia rozwoju społeczeństwa informacyjnego w Polsce do roku 2013, 2008.

2. Nojszewska E, Walewski J. Nowa definicja ochrony zdrowia i jej wpływ na poprawę jakości leczenia. Raport otwarcia Value Based Healthcare, Warsaw 2019.

3. Appendix No. $6 b$ to the Regulation No. 72/2011/DSOZ of the President of the National Health Fund of 20 October 2011

4. Buss T, Lichodziejewska M. Opieka paliatywna w Polsce - od idei do praktyki (również lekarza rodzinnego). Forum Med Rodz. 2008(2): 277-285.

5. The Act of 15 April 2011 on Medical Activity (Polish Journal of Laws of 2001 No. 112 item 654).

6. Regulation of the Minister of Health of 16 February 2016 amending the Regulation on guaranteed services within palliative and hospice care. (Polish Journal of Laws of 2020 item 457).

7. Act of 1 March 2018 on the amendment of certain acts in connection with the implementation of e-prescription. (Polish Journal of Laws of 2018 item 697; of 2019 item 1590).

8. Act of 5 December 1996 on Professions of Doctor and Dentist. (Polish Journal of Laws No. 28 item 152).

9. Act of 6 September 2001 on Pharmaceutical Law. (Polish Journal of Laws 2001 No. 126 item 1381).

10. Act of 12 May 2011 on coverage of drugs, foodstuffs for particular nutritional uses and medical devices. (Polish Journal of Laws of 2011 No. 122 item 696).

11. Regulation of the Minister of Health of 13 April 2018 on prescriptions. (Polish Journal of Laws of 2018 item 745). 
12. Reduction of the amount of a medicinal product subject to medical prescription when partial dispensing of e-prescription[Polish: Pomniejszanie ilości wydawanego leku przy częściowej realizacji e-recepty]. Announcement of the Ministry of Health of 28 November 2019. https://www. gov.pl/web/zdrowie/pomniejszanie-ilosci-wydawanego-leku-przy-czesciowej-realizacji-e-recepty (6 February 2020).

13. Act of 28 April 2011 on the health care information system (Polish Journal of Laws of 2011 No. 113 item 657).

14. Act of 19 July 2019 on the amendment of certain acts in connection with the implementation of solutions in the area of eHealth. (Polish Journal od Laws of 2019 item 1590).

15. Derkacz M, Chmiel-Perzyńska I, Michałojć-Derkacz M, et al. Michałojć-, Ocena wpływu nowych przepisów refundacyjnych na czas pracy lekarzy i jakość świadczonych usług medycznych. Fam Med Prim Care Rev. 2013; 15: 306-307.

16. Zaopatrzenie w wyroby medyczne - Informacje na stronie Narodowego Funduszu Zdrowia. http://www.nfz-szczecin. pl/8gjg1_zaopatrzenie_w_wyroby_medyczne.htm (27 February 2020)

17. Act of 17 February 2005 on the computerisation of activities of entities performing public tasks. (Polish Journal of Laws of 2005 No. 64 item. 565).

18. Regulation of the Minister of Digitisation of 10 September 2018 on the Trusted Profile and the Trusted Signature. (Polish Journal of Laws of 2018 item 1760).

19. Act of 27 August 2004 on health care services financed from public funds. (Polish Journal of Laws of 2004 No. 210 item 2135).
20. Regulation No. 154/2019/DEF of the President of the National Health Fund of 15 November 2019 on the conditions for conclusion and implementation of agreements on financing activation of Patient's Internet Accounts.

21. Johnston B, Kidd L, Wengstrom $Y$, et al. An evaluation of the use of Telehealth within palliative care settings across Scotland. Palliat Med. 2012; 26(2): 152-161, doi: 10.1177/0269216311398698, indexed in Pubmed: 21378067.

22. Hughes RA. Clinical practice in a computer world: considering the issues. J Adv Nurs. 2003; 42(4): 340-346, doi: 10.1046/j.1365-2648.2003.02625.x, indexed in Pubmed: 12752878.

23. Jaka dokumentacja medyczna winna być prowadzona w hospicjum domowym. https://www.prawo.pl/zdrowie/jaka-dokumentacja-medyczna-winna-byc-prowadzona-w-hospicjum-domowym,244028.html (24 March 2020).

24. http://www.eopieka.org.pl/ (24 March 2020).

25. Watanabe SM, Fairchild A, Pituskin E, et al. Improving access to specialist multidisciplinary palliative care consultation for rural cancer patients by videoconferencing: report of a pilot project. Support Care Cancer. 2013; 21(4): 1201-1207, doi: 10.1007/s00520-012-1649-7, indexed in Pubmed: 23161339.

26. Telemedycyna potrzebuje rozwiązań prawnych i kontraktów z NFZ - Zdrowie - Prawo.pl. https://www. prawo. $\mathrm{pl} / z d$ rowie/telemedycyna-potrzebuje-rozwiazan-prawnych-i-kontraktow-z-nfz,418103.html (24 March 2020). 


\section{Narzędzia usprawniające opiekę paliatywną: e-recepta i Internetowe Konto Pacjenta — analiza stanu}

\section{prawnego}

Artykuł jest tłumaczeniem pracy: Susławska N., Zimmermann A., Tools to improve palliative care: e-prescription and Patient's Internet Account - legal status analysis. Palliat. Med. Pract. 2020 tom 14, nr 1: 101-107.

Należy cytować wersję pierwotną.

Piśmiennictwo znajduje się na stronach 106-107.

\section{Streszczenie}

Wdrażanie nowych technologii jest odpowiedzią na wyzwania obecnego systemu ochrony zdrowia, takie jak starzejące się społeczeństwo czy rosnące koszty leczenia. Koncentracja na podnoszeniu jakości udzielanych świadczeń i zwiększaniu dostępności do leczenia gwarantuje poczucie bezpieczeństwa w procesie terapeutycznym. Wprowadzone nowelizacje prawa wdrażające ideę cyfryzacji systemu ochrony zdrowia mogą okazać się znacznym ułatwieniem zarówno dla personelu medycznego, jak i bliskich opiekujących się chorymi. Z nowych rozwiązań mogą skorzystać hospicja domowe, których funkcjonowanie jest znacznym wyzwaniem ze względów organizacyjnych i finansowych.

Celem pracy była analiza aktualnie obowiązujących przepisów prawa regulujących przepisywanie elektroniczne. Dodatkowo, oceniano wpływ e-recepty i powiązanych elementów e-zdrowia na dostępność do świadczeń opieki paliatywnej i ich jakość. Nowoczesne technologie komunikacyjne i informacyjne mogą rozwiązać wiele problemów związanych z dostępem, jakością i efektywnością kosztową usług medycznych, w szczególności dotyczących opieki paliatywnej. E-recepta to narzędzie, które w znaczący sposób może usprawnić opiekę nad pacjentem, dzięki ułatwionym zasadom przepisywania. Nowe zasady wystawiania i potwierdzania zleceń na wyroby medyczne stanowią również znaczne ułatwienie dla opiekunów chorych.

Palliat Med Pract 2020; 14, 2: 108-114

Słowa kluczowe: przepisywanie elektroniczne, e-zdrowie, telemedycyna, medycyna paliatywna, świadczenie opieki zdrowotnej, prawo farmaceutyczne

\section{Skróty}

u.z.I. - Ustawa z dnia 5 grudnia 1996 r. o zawodach lekarza i lekarza dentysty (Dz. U. 1997 Nr 28 poz. 152) u.p.f. - Ustawa z dnia 6 września 2001 r. Prawo farmaceutyczne (Dz.U. 2001 Nr 126 poz. 1381)
Platforma P1 — Elektroniczna Platforma Gromadzenia, Analizy i Udostępniania zasobów cyfrowych o Zdarze- niach Medycznych
SIM — System Informacji Medycznej
IKP — Internetowe Konto Pacjenta

\section{Adres do korespondencji:}

Natalia Susłowska

Zakład Prawa Medycznego i Farmaceutycznego, Gdański Uniwersytet Medyczny

e-mail: nataliasuslowska@gmail.com 
CSIOZ — Centrum Systemów Informacyjnych Ochrony Zdrowia

NFZ - Narodowy Fundusz Zdrowia

POZ — Podstawowa Opieka Zdrowotna

RAM - Rejestr Asystentów Medycznych

ZUS - Zakład Ubezpieczeń Społecznych

\section{Wstęp}

W 2019 roku nastąpił przełom w procesie informatyzacji systemu ochrony zdrowia - w okresie kilku miesięcy wdrożono w Polsce e-receptę, e-zwolnienie, elektroniczne zlecenie na wyroby medyczne, jak również upowszechniono dostęp do Internetowego Konta Pacjenta. Wszystkie działania to konsekwencje przyjętej w 2008 roku strategii rozwoju społeczeństwa informacyjnego w Polsce [1]. Cyfryzacja opieki zdrowotnej jest rozwiązaniem, które podwyższa jakość świadczonych usług medycznych, umożliwia szybsze i trafne podejmowanie decyzji terapeutycznych. Wdrażanie nowych technologii jest odpowiedzią na wyzwania obecnego systemu ochrony zdrowia, takie jak starzejące się społeczeństwo czy rosnące koszty leczenia. Koncentracja na podnoszeniu jakości udzielanych świadczeń i zwiększaniu dostępności do leczenia gwarantuje poczucie bezpieczeństwa w procesie terapeutycznym [2].

Badania dotyczące dostępności do opieki paliatywnej wykazały, że nadal w niektórych powiatach w Polsce brak tego rodzaju jednostki. Spośród dostępnych form opieki paliatywnej w Polsce najczęściej wykorzystywane jest hospicjum domowe. W Zarządzeniu Prezesa NFZ [3] określono minimalne wymagania kadrowe, jakie musi spełniać placówka świadcząca opiekę paliatywną w warunkach domowych: jeden lekarz ma pod opieką do 30 pacjentów. Zgodnie z warunkami umowy zawartej z NFZ, lekarz musi posiadać przynajmniej rozpoczętą specjalizację medycyny paliatywnej lub ukończony kurs z tego zakresu. Podstawowym wymogiem świadczenia opieki paliatywnej w warunkach domowych jest całodobowa dostępność [4]. Wymagania stawiane hospicjom domowym powodują, że funkcjonowanie takiej placówki stanowi wyzwanie ze względów organizacyjnych i finansowych.

Nowelizacje prawa wdrażające ideę cyfryzacji systemu ochrony zdrowia mogą stanowić znaczne ułatwienie dla personelu medycznego i opiekunów chorych. Obecne regulacje prawne umożliwiają opiekę nad pacjentem, bez konieczności kontaktu bezpośredniego. Podstawę udzielania świadczeń zdrowotnych na odległość stanowi art. 3 ust. 1 ustawy z dnia 15 kwietnia 2011 roku o działalności leczniczej, który wskazuje, że działalność lecznicza może być prowadzona z wykorzystaniem systemów teleinforma- tycznych [5]. Dodatkowo art. 2 ust. 4 Ustawy z dnia 5 grudnia 1996 roku o zawodach lekarza i lekarza dentysty wskazuje świadczenia, które lekarz może udzielać za pośrednictwem systemów łączności: badanie stanu zdrowia, rozpoznawanie chorób i ich zapobieganie. Ponadto, leczenie i rehabilitacja oraz udzielanie porad mogą odbywać się bez osobistego kontaktu z pacjentem. Lekarz jest również upoważniony do zaocznego wydawania orzeczeń i opinii lekarskich. Warto zwrócić uwagę, że najnowsze zapisy ustawy pozwalają na wystawienie recepty na kontynuację leczenia pacjenta bez uprzedniego badania, jeżeli jest to uzasadnione stanem zdrowia pacjenta mającym odzwierciedlenie w dokumentacji medycznej. Takie same zasady dotyczą zleceń na wyroby medyczne (art. 42 ust. 2 u.z.l). Przepisy wprowadzone w dniu 16 marca 2020 roku uzupełniły Rozporządzenie w sprawie świadczeń gwarantowanych z zakresu opieki paliatywnej i hospicyjnej o zapisy, które legalizują i dopuszczają realizację porad i wizyt domowych w ramach hospicjum domowego z wykorzystaniem systemów teleinformatycznych. Warunkiem użycia nowych systemów łączności jest zapewnienie, że postępowanie takie nie zagraża pogorszeniem stanu zdrowia pacjenta [6]. Obowiązująca obecnie e-recepta i elektroniczne zlecenie na wyroby medyczne stanowią znaczne ułatwienie w leczeniu pacjentów, w tym również objętych opieką paliatywną. Celem pracy była analiza aktualnie obowiązujących przepisów prawa regulujących przepisywanie drogą elektroniczną. Ponadto, oceniano wpływ e-recepty i powiązanych elementów e-zdrowia na dostępność do świadczeń z zakresu opieki paliatywnej i ich jakość.

\section{E-recepta i e-zlecenie na wyroby medyczne}

W dniu 1 marca 2018 roku weszły w życie zapisy ustawy o zmianie niektórych ustaw w związku z wprowadzeniem e-recepty [7]. Wśród 8 zmienionych aktów prawnych znalazły się między innymi ustawa $z$ dnia 5 grudnia 1996 roku o zawodach lekarza i lekarza dentysty [8], Ustawa z dnia 6 września 2001 roku Prawo farmaceutyczne [9], jak również Ustawa z dnia 12 maja 2011 roku o refundacji leków, środków spożywczych specjalnego przeznaczenia żywieniowego i wyrobów medycznych [10]. Artykuł 95b ustawy Prawo farmaceutyczne wskazuje przepisywanie elektroniczne, jako preferencyjny sposób wystawiania recept. Recepta papierowa może być wystawiona w określonych przypadkach:

- brak dostępu do systemu teleinformatycznego umożliwiającego obsługę e-recept;

- konieczność przepisania leku dla osoby o nieustalonej tożsamości;

- czasowe wykonywanie zawodu lekarza na terenie Rzeczypospolitej Polskiej; 
- zalecanie leku w procedurze importu docelowego. Przepisując lek dla siebie (pro auctore), jak również dla członka rodziny (pro familiae) można korzystać z papierowej wersji recepty. Warto zauważyć, że od sierpnia 2019 roku rozszerzono katalog osób, którym osoba uprawniona może zalecić lek. Obecnie, poza krewnymi w linii prostej i małżonkami, do tej grupy zalicza się również krewnych w linii bocznej do stopnia pokrewieństwa pomiędzy dziećmi rodzeństwa, a także osoby pozostające we wspólnym pożyciu z osobą wystawiającą. Zgodnie $z$ artykułem 56 ust. 2 ustawy z dnia 28 kwietnia 2011 roku o systemie informacji w ochronie zdrowia, recepty w postaci papierowej, które nie spełniają powyższych przesłanek, mogły być wystawiane do 7 stycznia 2020 roku. W celu rozpoczęcia przepisywania elektronicznego, placówki medyczne zobowiązano do połączenia z Elektroniczną Platformą Gromadzenia, Analizy i Udostępnienia Zasobów Cyfrowych o Zdarzeniach Medycznych (platforma P1) do dnia 31 grudnia 2019 roku. Prawo farmaceutyczne określa w sposób szczegółowy dane, które muszą znaleźć się na recepcie, aby mogła zostać zrealizowana (tab. 1). Zakres tych informacji jest zbliżony dla recept papierowych i elektronicznych, niezależnie od poziomu refundacji przepisanych produktów.

Osoba zlecająca leki zobligowana jest do wskazania daty wystawienia recepty, a w przypadku recepty z od- roczonym terminem realizacji, określić datę realizacji od dnia. Podczas jednej wizyty lekarz może wystawić pacjentowi ilość leku niezbędną do 360 dni leczenia wyliczonego na podstawie określonego na recepcie sposobu dawkowania. Ponadto, osoba uprawniona do wystawiania recept, kierując się aktualną wiedzą medyczną, może określić termin realizacji e-recepty do 365 dni. W przypadku braku oznaczenia wydłużonego okresu ważności recepty, pacjent powinien wykupić przepisane produkty lecznicze w okresie 30 dni [11]. Wydłużona ważność recepty nie dotyczy produktów leczniczych, dla których odrębne przepisy dokładnie określają termin realizacji, czyli antybiotyki do stosowania wewnętrznego i parenteralnego, produkty immunologiczne wytwarzane indywidualnie dla pacjenta i leki zawierające środki psychotropowe i substancje odurzające. W przypadku polecenia pilnej realizacji recepty, należy opatrzyć ją określeniem „cito”.

Istotne jest, że po upływie 30 dni od daty wystawienia e-recepty (albo daty realizacji od dnia), jest ona realizowana $z$ wyłączeniem dni stosowania, które już upłynęły. To oznacza, że pomimo określonej daty ważności recepty, jako 365 dni, pacjent chcąc otrzymać całą przepisaną ilość leku, musi rozpocząć realizację recepty w czasie pierwszych 30 dni od jej wystawienia. Zgodnie z Komunikatem Ministerstwa Zdrowia z dnia 28 listopada 2019 roku, pomniejsze-

Tabela 1. Zestawienie danych obowiązkowych na recepcie wystawionej w postaci elektronicznej — stan prawny na dzień 6.02.2020 r.

\begin{tabular}{|c|c|}
\hline Dane dotyczące pacjenta & $\begin{array}{l}\text { Imię i nazwisko } \\
\text { Adres (nazwa miejscowości, ulica, numer domu, kod pocztowy, numer lokalu, jeżeli } \\
\text { nadano) } \\
\text { PESEL lub seria i numer paszportu w przypadku obcokrajowców } \\
\text { Data urodzenia pacjenta, w przypadku gdy nie można jej ustalić na podstawie innych } \\
\text { danych zamieszczonych na recepcie } \\
\text { Kod uprawnień dodatkowych pacjenta, jeżeli dotyczy }\end{array}$ \\
\hline $\begin{array}{l}\text { Dane dotyczące podmio- } \\
\text { tu, w którym wystawiono } \\
\text { receptę }\end{array}$ & $\begin{array}{l}\text { Nazwa miejsca udzielania świadczenia } \\
\text { Adres (nazwa miejscowości, kod pocztowy, ulica, numer domu, numer lokalu, jeżeli } \\
\text { zostały nadane), a w przypadku osób wykonujących działalność leczniczą wyłącznie w } \\
\text { miejscu wezwania - adres miejsca przyjmowania wezwań i miejsca przechowywania } \\
\text { dokumentacji medycznej } \\
\text { Identyfikator miejsca udzielania świadczeń (kod utworzony z części kodu z systemu } \\
\text { resortowych kodów identyfikacyjnych) } \\
\text { Numer telefonu dostępny w miejscu udzielania świadczenia }\end{array}$ \\
\hline $\begin{array}{l}\text { Dane dotyczące osoby } \\
\text { wystawiającej receptę }\end{array}$ & $\begin{array}{l}\text { Imię i nazwisko osoby wystawiającej receptę } \\
\text { Kwalifikacje zawodowe, w tym posiadany tytuł zawodowy } \\
\text { Numer Prawa Wykonywania Zwodu } \\
\text { Numer telefonu do bezpośredniego kontaktu z osobą wystawiającą receptę } \\
\text { Kwalifikowany podpis elektroniczny, podpis zaufany lub podpis osobisty albo z wyko- } \\
\text { rzystaniem sposobu potwierdzania pochodzenia i integralności danych dostępnego w } \\
\text { systemie ZUS }\end{array}$ \\
\hline $\begin{array}{l}\text { Dane dotyczące przepisa- } \\
\text { nego produktu lecznicze- } \\
\text { go, środka spożywczego } \\
\text { specjalnego przeznaczenia } \\
\text { żywieniowego lub wyrobu } \\
\text { medycznego }\end{array}$ & $\begin{array}{l}\text { Nazwa powszechnie stosowana (międzynarodowa lub handlowa) } \\
\text { Postać, jeżeli przepisany produkt występuje w więcej niż jednej postaci } \\
\text { Dawka, jeżeli przepisany produkt występuje w więcej niż jednej dawce } \\
\text { llość przepisanego produktu } \\
\text { Sposób dawkowania }\end{array}$ \\
\hline
\end{tabular}


nie ilości wydawanego produktu leczniczego, dokonywane jest wyłącznie przy pierwszej częściowej realizacji recepty [12]. Warto zwrócić uwagę na fakt, że jednorazowo pacjent może otrzymać $z$ apteki maksymalnie ilość produktu niezbędną do $180 \mathrm{dni}$ stosowania wyliczonego na podstawie określonego na recepcie sposobu dawkowania. W konsekwencji pacjent, któremu przepisano 360 dni kuracji lekiem, w celu wykupienia całości zaleconej terapii, musi odwiedzić aptekę przynajmniej 2-krotnie. W przepisach nie określono minimalnego czasu, jaki musi upłynąć pomiędzy kolejnymi realizacjami recepty, co oznacza, że dopuszczalne jest wykupienie całości 360 dni kuracji lekiem w dwa dni, pod warunkiem dokonania dwóch osobnych transakcji fiskalnych.

W przeciwieństwie do recept papierowych, na jednym dokumencie, można wystawić maksymalnie jeden produkt leczniczy. W przypadku wystawienia więcej niż jednej e-recepty, osoba wystawiająca może, w celu usprawnienia ich realizacji, połączyć te recepty $w$ pakiet. Jeden pakiet może zawierać do pięciu e-recept. Recepta wystawiona w postaci elektronicznej jest zapisywana w SIM, który jest systemem teleinformatycznym służącym do przetwarzania danych dotyczących udzielonych, udzielanych i planowanych świadczeń zdrowotnych, które są udostępniane przez usługodawców [13]. Treść e-recepty, która została zapisana w SIM nie może być modyfikowana. W przypadku konieczności naniesienia zmian na recepcie, należy ją anulować, a następnie wystawić nową. Anulować receptę może tylko osoba, która ją wystawiła. Recepty w postaci elektronicznej są przechowywane w SIM przez okres co najmniej 5 lat, licząc od zakończenia roku kalendarzowego, w którym zostały one zrealizowane. W przypadku recept na leki refundowane, czas ten liczony jest od końca roku kalendarzowego, w którym nastąpiła refundacja.

Zgodnie $z$ art. 96b u.p.f., obowiązkowe jest, aby pacjent, któremu została wystawiona recepta $\mathrm{w}$ formie elektronicznej, otrzymał następujące informacje:

- klucz dostępu do e-recepty lub pakietu e-recept (40 cyfr);

- kod dostępu umożliwiający zrealizowanie recepty w aptece $w$ połączeniu z numerem PESEL (4 cyfry);

- identyfikator e-recepty, który został nadany przez system P1 podczas rejestracji do Rejestru Placówek Wykonujących Działalność Leczniczą;

- datę wystawienia recepty oraz data realizacji od dnia;

- imię i nazwisko pacjenta;

- dane osoby wystawiającej receptę, w tym numer prawa wykonywania zawodu i numer telefonu do bezpośredniego kontaktu;

- dane dotyczące przepisanego produktu lecznicze- go, w tym jego nazwę, postać, dawkę, ilość oraz sposób dawkowania.

Wymienione informacje zawarte są również w IKP. Osoba wystawiająca receptę powinna upewnić się, że pacjent posiada dostęp do IKP, w przeciwnym przypadku, wskazane dane muszą zostać przekazane podczas wizyty.

Ustawa określa dokładnie trzy sposoby przekazania pacjentowi dostępu do e-recepty i do wyżej wymienionych informacji. Według art. 96b ust. 2 u.p.f. e-receptę można wysłać drogą elektroniczną na wskazany adres e-mail, bądź wiadomością tekstową na numer telefonu. Należy zaznaczyć, że wysłana wiadomość SMS musi zawierać co najmniej czterocyfrowy kod dostępu wraz z informacją o konieczności podania numeru PESEL podczas realizacji recepty $w$ aptece. Udostępnienie e-recepty w ten sposób jest możliwe wyłącznie, jeżeli pacjent udostępni w systemie informacji w ochronie zdrowia swoje dane w postaci adresu e-mail i numeru telefonu. W przypadku braku wskazania przez pacjenta wymienionych danych kontaktowych w systemie, osoba wystawiająca ma obowiązek przekazać dostęp do e-recepty i niezbędnych danych za pomocą wydruku informacyjnego, który powinien być wydany pacjentowi również na każde jego żądanie.

Istotne jest, że zgodnie $z$ art. $96 b$ ust. 3 u.p.f. wydruk informacyjny może zostać wydany wyłącznie przez osobę wystawiającą receptę. $Z$ niniejszego zapisu wynika, że w procesie przekazywania wydruku nie mogą uczestniczyć osoby pośrednie, na przykład rejestratorka czy pielęgniarka. Rozwiązanie dla tego ograniczenia wprowadziła Ustawa z dnia 19 lipca 2019 roku o zmianie niektórych ustaw, w związku z wdrażaniem rozwiązań w obszarze e-zdrowia [14]. Wspomniane regulacje umożliwiły udzielenie upoważnienia do wystawiania recept elektronicznych w imieniu lekarza osobom wykonującym zawód medyczny i wykonującym czynności pomocnicze przy udzielaniu świadczeń zdrowotnych. Do tego grona zalicza się również personel zajmujący się utrzymaniem systemu teleinformatycznego obsługującego e-recepty. Wymienione osoby mogą być obecne przy udzielaniu świadczeń zdrowotnych, jak również są dopuszczone przez podmiot leczniczy do przetwarzania danych osobowych pacjentów. Upoważnienie do wystawiania recept może zostać udzielone maksymalnie na okres 12 miesięcy. Konsekwencją omawianego upoważnienia jest obowiązek zachowania poufności wszelkich informacji uzyskanych w związku z wystawianiem recepty, również po śmierci pacjenta. Udzielenie upoważnienia może nastąpić za pośrednictwem RAM, którego administratorem jest Ministerstwo Zdrowia [8]. Należy zaznaczyć, że wsparcie asystenta medycznego może być wykorzystywane wyłącznie w przypadku 
recept elektronicznych, a prawo nie przewiduje takiej pomocy przy wystawianiu recept papierowych.

W przeciwieństwie do recept papierowych, przepisy prawa nie określają formatu wydruku informacyjnego e-recepty. Dokument ten może przyjąć format dotychczasowych recept lub inny, co zależy wyłącznie od ustawień drukarki w gabinecie lekarskim. W sytuacji udzielania świadczenia zdrowotnego w miejscu wezwania, dopuszczalne jest przekazanie e-recepty w innej, uzgodnionej z pacjentem postaci, zawierającej co najmniej klucz dostępu lub kod dostępu do recepty i nazwę zaleconego produktu leczniczego. Zgodnie z obowiązującymi przepisami, niepoprawne jest przekazanie pacjentowi wyłącznie kartki z zapisanym odręcznie kodem dostępu do e-recepty, z pominięciem pozostałych obowiązkowych danych.

Zgodnie z u.z.l. osoba uprawniona do wystawienia recepty jest zobowiązana do określenia poziomu odpłatności za dany produkt leczniczy, jeżeli w wykazie leków refundowanych występuje on w co najmniej dwóch odpłatnościach [8]. Obowiązek ten spotyka się z niezadowoleniem i protestami środowiska lekarskiego. Odnotowane zostały przypadki, w których lekarz z powodu ograniczonego czasu bądź niedostępnego przystępnego źródła wiedzy na temat poziomów refundacji, bądź z obawy przed karą, zalecił lek pełnopłatnie, pomimo posiadania przez pacjenta prawa do refundacji. Ponadto, badania prowadzone w 2013 roku wykazały, że ten obowiązek wydłuża prawie 2-krotnie czas poświęcony na wystawienie recepty papierowej [15].

Informatyzacja systemu opieki zdrowotnej ma na celu usprawnienie i ułatwienie wykonywania świadczeń zdrowotnych. Z związku z tym, mocą Ustawy z dnia 28 kwietnia 2011 roku o systemie informacji w ochronie zdrowia, CSIOZ jest zobowiązane do nieodpłatnego udostępnienia narzędzia informatycznego służącego do określania poziomu odpłatności dla poszczególnych produktów leczniczych na e-recepcie. Dane umożliwiające zainstalowanie tego narzędzia w programie gabinetowym, jak również jego aktualizację, minister zdrowia powinien zamieścić w Biuletynie Informacji Publicznej [13]. Istotne, że ani lekarz, ani podmiot leczniczy nie poniosą odpowiedzialności za ewentualne skutki błędnego działania tego narzędzia polegającego na nieodpowiednim określeniu poziomu odpłatności [8].

Kolejnym ułatwieniem dla pacjentów przewlekle chorych są nowe zasady potwierdzania zleceń na wyroby medyczne. Wielu chorych objętych opieką paliatywną codziennie korzysta z wyrobów medycznych, takich jak pieluchomajtki, cewniki urologiczne, poduszki i materace przeciwodleżynowe. Od 1 stycznia 2020 roku istnieje możliwość elektronicznego potwierdzania zlecenia na zaopatrzenie w powyższe produkty, a od 1 kwietnia 2020 roku taka forma wery- fikacji będzie standardem. Do tej pory pacjenci, bądź ich opiekunowie, zmuszeni byli do comiesięcznych wizyt w oddziale NFZ, w celu uzyskania pieczątki potwierdzającej uprawnienia do nabycia refundowanych wyrobów medycznych. Przy korzystaniu z nowych wzorów zleceń, pacjent będzie mógł udać się do apteki bezpośrednio po odebraniu zlecenia. Nowe zasady umożliwiają wystawianie i potwierdzanie zleceń niezależnie od miejsca zamieszkania pacjenta [16]. Istotne, że zlecenie może być wystawione po wcześniejszym badaniu pacjenta, które może być przeprowadzone osobiście bądź za pośrednictwem systemów łączności na odległość. W sytuacji przepisywania wyrobów medycznych, które przysługują pacjentowi comiesięcznie, zlecenie może zostać wystawione wyłącznie na podstawie zapisów dokumentacji medycznej [10].

\section{Internetowe Konto Pacjenta}

Internetowe Konto Pacjenta to moduł platformy P1, który umożliwia dostęp do danych chorych zapisanych w SIM i w Systemie Rejestru Usług Medycznych Narodowego Funduszu Zdrowia [13]. Internetowe Konto Pacjenta umożliwia pacjentowi bądź jego ustawowemu przedstawicielowi dostęp do informacji na temat udzielonych i planowanych świadczeń zdrowotnych, jak również kwoty środków publicznych wydanych na ich sfinansowanie. W części poświęconej wystawionym i zrealizowanym e-receptom można zapoznać się z wysokością kwoty refundacji dla poszczególnych produktów leczniczych stosowanych przez pacjenta. Poprzez IKP pacjent może upoważnić wybrane osoby do dostępu do dokumentacji medycznej, jak również udostępnić dane osobowe lub jednostkowe dane medyczne świadczeniodawcy w zakresie czasowym i przedmiotowym określonym przez pacjenta. W IKP świadczeniobiorca może wskazać osobę upoważnioną do uzyskiwania wszelkich informacji o stanie zdrowia.

Kolejną funkcją IKP, istotną z punktu widzenia bezpieczeństwa pacjenta, jest dostęp do informacji o produktach leczniczych, które zostały wycofane z obrotu, jeżeli zostały przez niego nabyte na podstawie recepty. Dzięki obowiązkowi generowania elektronicznego Dokumentu Realizacji Recepty, usługobiorca posiada stały dostęp do danych dotyczących wydanego produktu leczniczego, uwzględniając jego datę ważności i numer serii. Zapisane są również informacje dotyczące apteki, z której lek został wydany i dane pracownika realizującego receptę. Warto zaznaczyć, że wymienione możliwości IKP są tylko nielicznymi przykładami, które są kluczowe z punktu widzenia funkcjonalności recepty elektronicznej.

Internetowe Konto Pacjenta całkowicie likwiduje anonimowość pracowników systemu ochrony zdrowia, a dane dotyczące procesu leczenia pacjenta są 
transparentne. Warto zauważyć, że IKP umożliwia w prosty sposób składanie wniosków i skarg do Rzecznika Praw Pacjenta, Ministra Zdrowia i Narodowego Funduszu Zdrowia. Oczekuje się, że takie rozwiązanie podniesie jakość udzielanych świadczeń zdrowotnych i usług farmaceutycznych.

Dostęp do IKP jest możliwy po uwierzytelnieniu usługobiorcy, jego przedstawiciela ustawowego lub osoby przez niego upoważnionej przy użyciu środka identyfikacji elektronicznej [17]. Podstawowym środkiem identyfikacji elektronicznej, który pacjent może wykorzystać do uzyskania dostępu do IKP jest profil zaufany, który może mieć każdy obywatel posiadający numer PESEL. Aby rozpocząć posługiwanie się profilem zaufanym należy złożyć wniosek elektroniczny, który w dalszej kolejności trzeba potwierdzić na jeden z trzech sposobów. Pierwszy wymaga wizyty w punkcie potwierdzającym, gdzie osoba upoważniona stwierdza tożsamość osoby wnioskującej na podstawie przedstawionych dokumentów. Dodatkowo, osoba wnioskująca potwierdza chęć posiadania profilu zaufanego, składając własnoręczny podpis na wniosku w postaci papierowej. Wnioskodawca może również samodzielnie dokonać potwierdzenia profilu zaufanego, jeżeli posiada kwalifikowany podpis elektroniczny bądź wykorzystując konto bankowości elektronicznej. Potwierdzony i aktywny profil zaufany umożliwia złożenie podpisu elektronicznego [18].

Funkcję punktu potwierdzającego może pełnić Konsul, Naczelnik Urzędu Skarbowego, Wojewoda, ZUS lub NFZ, który może nadać uprawnienia do potwierdzania profilu zaufanego $\mathrm{w}$ swoim imieniu osobom zatrudnionym w podmiotach realizujących zadania z zakresu POZ. Niniejsze uprawnienia może uzyskać lekarz, pielęgniarka lub położna POZ, jak również inna osoba zatrudniona w takim podmiocie, pod warunkiem zgłoszenia danych osobowych (imię, nazwisko, PESEL) do NFZ [17]. Pracownicy przychodni POZ mogą zatem pomagać pacjentom aktywować dostęp do IKP za wynagrodzeniem. Istnieją bowiem zapisy w prawie, że w latach 2020-2022 minister zdrowia może przekazać do NFZ dofinansowanie w wysokości 150000 zł na pełnienie funkcji punktów potwierdzających profil zaufany przez świadczeniodawców POZ i na kampanię promującą aktywowanie IKP. Wysokość dofinansowania jest uzależniona od liczby aktywowanych IKP przez personel przychodni POZ [19]. Zgodnie z Zarządzeniem Prezesa NFZ wynagrodzenie za aktywowanie jednego IKP poprzez potwierdzenie profilu zaufanego pacjenta wynosi 36,90 zł brutto dla pierwszych 150 aktywowanych IKP [20]. Od niedawna publiczna aplikacja mobilna mObywatel daje również możliwość dostępu do niezrealizowanych recept elektronicznych.

\section{Podsumowanie}

Celem opieki paliatywnej jest zapewnienie możliwie najskuteczniejszego leczenia objawów, łagodzenie cierpienia, wsparcie psychosocjalne i duchowe chorych i opiekunów oraz poprawa jakości życia pacjentów [21]. Jednym z kluczowych elementów opieki jest zabezpieczenie chorych w niezbędne leki (zwłaszcza przeciwbólowe) i opatrunki specjalistyczne oraz wyroby medyczne do zapewnienia komfortu i higieny pacjentów. E-recepta to narzędzie, które w znaczący sposób może usprawnić opiekę zapewnianą chorym, dzięki ułatwionym zasadom przepisywania i kontynuacji leczenia. Nowe zasady wystawiania i potwierdzania zleceń na wyroby medyczne stanowią również znaczne ułatwienie dla opiekunów ciężko chorych, którzy zostali zwolnieni z obowiązkowych, comiesięcznych wizyt w oddziałach NFZ. Internetowe Konto Pacjenta zapewnia możliwość łatwego dostępu do danych medycznych zarówno lekarzom, jak i opiekunom chorych, co sprzyja monitorowaniu i zarządzaniu w opiece paliatywnej.

Potencjał wielu aplikacji mobilnych i nowych technologii informatycznych w opiece zdrowotnej jest obiecujący. Współczesne rozwiązania technologiczne pozwalają na zwiększone zaangażowanie pacjenta w proces leczenia i na stałe monitorowanie objawów choroby. Wykorzystywanie tych narzędzi może zatem zapobiegać niepotrzebnym hospitalizacjom i nagłym interwencjom medycznym [22]. Nowoczesne technologie komunikacyjne i informacyjne mogą rozwiązać szereg problemów związanych z dostępem, jakością i efektywnością kosztową usług medycznych [21]. Jednostki opieki paliatywnej, w tym również hospicja domowe, są zobowiązane zgodnie z art. 11 Ustawy z dnia 28 kwietnia 2011 roku o systemie informacji w ochronie zdrowia, do prowadzenia dokumentacji medycznej w formie elektronicznej [13]. Lekarze udzielający świadczeń w ramach opieki domowej powinni prowadzić dokumentację medyczną zgodnie z zasadami odnoszącymi się do dokumentacji medycznej wizyt domowych. Dodatkowo, wizyta personelu hospicjum domowego, wiąże się z każdorazowym wypełnieniem karty wizyt w domu chorego [23]. Jednak różnorodność świadczeń w hospicjach domowych udzielanych przez personel medyczny różnych zawodów powoduje, że opracowanie systemu elektronicznego dokumentowania dostosowanego do potrzeb opieki paliatywnej stanowi istotne wyzwanie. Na rynku pojawiają się komercyjni usługodawcy dostarczający oprogramowania przeznaczone do prowadzenia dokumentacji medycznej w jednostkach opieki paliatywnej. Oferowane aplikacje pozwalają na przygotowanie recept $\mathrm{w}$ domu pacjenta, a dokonywane wpisy są 
widoczne dla pozostałych pracowników medycznych opiekujących się danym pacjentem [24].

Wprowadzenie telemedycyny do opieki paliatywnej skutkuje zmniejszeniem wydatków na konsultacje i skróceniem czasu lekarzy spędzonego podczas transportu, wzrostem satysfakcji pacjentów i rodzin [25]. Telemedycyna jest obecnie wykorzystywana w około $8 \%$ placówek medycznych w Polsce [26]. Informatyzacja systemu ochrony zdrowia stanowi kluczowy czynnik warunkujący rozwój tego obszaru, przy czym e-recepta, e-skierowania, e-zwolnienia i e-zlecenia na wyroby medyczne dają szansę na zwiększenie efek- tywności tego rodzaju świadczeń. Korzyści wynikające ze stosowania nowoczesnych technologii w opiece paliatywnej przedstawione $w$ niniejszym artykule stanowią argument za koniecznością rozpowszechnienia i przeznaczenia większych środków finansowych na ich rozwój.

\section{Konflikt interesów}

Autorzy deklarują brak konfliktu interesów.

\section{Finansowanie}

Badanie nie było finansowane. 